\title{
UTILIZATION OF EFFELUENT FISH FARMS IN TOMATO CULTIVATION
}

\author{
Yasmin A. Hassan*, El-Sayed G. Khater**, Adel H. Bahnasawy**, \\ Abd El-Hakeem S. Shams** and Mohamed S. Hassaan***
}

\section{ABSTRACT}

The main objective of this research is to study to which extent the content of nutrients in water farming is sufficient for growing tomato plants. The obtained results indicated that the nutrients consumption increased with increasing the flow rate. The root and shoot length increased with increasing effluent flow rate, when the effluent flow rate increased from 4.0 to $6.0 \mathrm{~L} \mathrm{~h}^{-1}$, the length of root and shoot significantly increased from 50.33 to 55.33 and 149.33 to $191.33 \mathrm{~cm}$, respectively, at the end of growing period. The fresh and dry mass of shoot significantly increased from 998.01 to 1372.10 and 83.71 to $275.09 \mathrm{~g}$ plant $^{-1}$, respectively, with increasing flow rate from 4.0 to $6.0 \mathrm{~L} \mathrm{~h}^{-1}$. The fresh and dry mass of root significantly increased from 388.07 to 423.91 and 30.37 to 38.98 g plant $^{-}$ ${ }^{1}$, respectively, with increasing flow rate from 4.0 to $6.0 \mathrm{~L} \mathrm{~h}^{-1}$. The fruit yield significantly increased from 1.06 to $1.37 \mathrm{~kg}$ plant $^{-1}$ with increasing flow rate from 4.0 to $6.0 \mathrm{~L} \mathrm{~h}^{-1}$. The fruit mass and number of fruits increased from 75.07 to $81.32 \mathrm{~g}$ and 14.12 to 16.85 with increasing flow rate from 4.0 to $6.0 \mathrm{~L} \mathrm{~h}^{-1}$. The water use efficiency increased from 5.54 to $7.16 \mathrm{~kg} \mathrm{~m}^{-3}$ with increasing flow rate from 4.0 to $6.0 \mathrm{~L} \mathrm{~h}^{-1}$. Using the effluent fish farm could save fertilizers which equivalents $0.13 \mathrm{LE} / \mathrm{kg}$ fruits (130 LE/ton fruits). Besides it is considered as an organic product which is safe for the human health.

Keywords: Aquaponics - Hydroponics - Aquaculture -fish farm

\section{INTRODUCTION}

opulation of Egypt is gradually increasing and there is a necessity
to find out new techniques to reduce the gap between population
needs and agricultural production. One of the new techniques called "aquaponics" is which we can utilize the outputs of fish farming in growing vegetables, i. e., lettuce, cucumber, tomato, cabbage and so on.

\footnotetext{
* Graduate Student of Agric. Eng. Dep., Fac. of Agric., Benha Univ., Egypt

** Fac. of Agric., Benha Univ., Egypt

*** NIOF Res. Inst., Agric. Res. Center, Egypt
} 
In this technique a minimum requirements of nutrients could be used, furthermore removal the fish feces (Khater, 2006).

Aquaponics is the integration of aquaculture (fish farming) and hydroponics (growing plants without soil). In aquaponic system the fish consume food and excrete waste primarily in the form of ammonia. Bacteria convert the ammonia to nitrite and then to nitrate (Diver, 2000; Bromes, 2002; Rakocy, 2002; Selock, 2003; Lee, 2004; Okimoto, 2004; Karen, 2005; Nelson, 2006a,b and c; Nelson, 2008; Graber and Junge, 2009; Suits, 2010).

Aquaponics has several advantages over other recirculating aquaculture systems and hydroponic systems that use inorganic nutrient solutions. The hydroponic component serves as a biofilter, and therefore a separate biofilter is not needed as in other recirculating systems. Aquaponic systems have the only biofilter that generates income, which is obtained from the sale of hydroponic produce such as vegetables, herbs and flowers (Rakocy and Hargreaves, 1993).

Aquaponic system is one of the economical solutions for getting benefits from the water-waste from the fish farms as it save nutrients and produce fresh vegetables. With using this system successively its cost will be decreased and became more economic. The produced plants via this system considered as an organic product which is more safe for human consumption (Khater and Ali, 2015).

Small proportion of ammonia is toxic to fish, when as nitrate is not toxic to fish. If nitrate increased over a specific limit it will be toxic to fish eaters (human being) and cause nitrate pollution and the eaters will suffer from methamoglobnia disease. The blood of the affected people became brown and will not be able to carry oxygen to the rest of human organs (Tuker and Boyed, 1985). To avoid this problem in aquaculture, part of water should be discharged daily and add fresh water instead. Another solution to this problem is establishing hydroponic system attached to the aquaculture and cultivates plants in the hydroponics in order to save discharged-water and gets use of existing nitrate.

Benefits of aquaponics are conservation of water resources and plant nutrients, intensive production of fish protein and reduced operating costs relative to either system in isolation. Water consumption in integrated 
systems including tilapia production is less than $1 \%$ of the required in pond culture to produce equivalent yields (Rakocy, 2002).

Tomato is one of the most important crops worldwide, because tomato is the second most important vegetable in the world after potato, with an annual production of 161.8 million tons in 2012. Tomato is one of the most important economic vegetable crops, practiced by the Egyptian farmers. The total cultivated area of watermelon is about 454800 Faddens and total production of tomato in 2012 was 8.6 million tons (FAO, 2012). The gradually increasing of production costs, it is required to maximize the utilization of available resources nutrients in the recycling water one of these resources, therefore, the main objective of this investigation was to study to which extent the content of nutrients in water farming is sufficient for growing tomato plants.

\section{MATERIALS AND METHODS}

The experiment was carried out at National Institute of Oceanography and Fisheries (NIOF) El-Knater El-Khiria, Kalubia Governorate. During 2014 season.

\subsection{System Description:}

Figure (1) illustrates the experimental setup. It shows the recirculating aquaculture system which consists of fish tanks, sump tank, hydroponic units and pumps under two greenhouses.

The system consists of five rectangular concrete tanks were used for fish culture. Dimensions of each tank are $8 \mathrm{~m}$ long, $5 \mathrm{~m}$ wide and $1.5 \mathrm{~m}$ high. The water volume used in each tank was $40 \mathrm{~m}^{3}$. Each tank has an inlet pipe and two types of outlets pipe. The inlet pipes for adding fresh water to fish tank, two types of outlets for one of them is a mechanical spillway which carries the normal expected water flow from the tank and can be designed to either partially or completely drain the tank to facilitate harvest. The second one is an emergency spillway which used to remove the exceed water capacity of tank.

The rectangular concrete tank was used in this system for removal solid wastes. Dimensions of tank are $3 \mathrm{~m}$ long, $2 \mathrm{~m}$ wide and $0.5 \mathrm{~m}$ high. The water volume used in each tank was $2.4 \mathrm{~m}^{3}$. Polyethylene sheets were used as a media for solids removal and carry bacteria in the system to improve the water quality. 


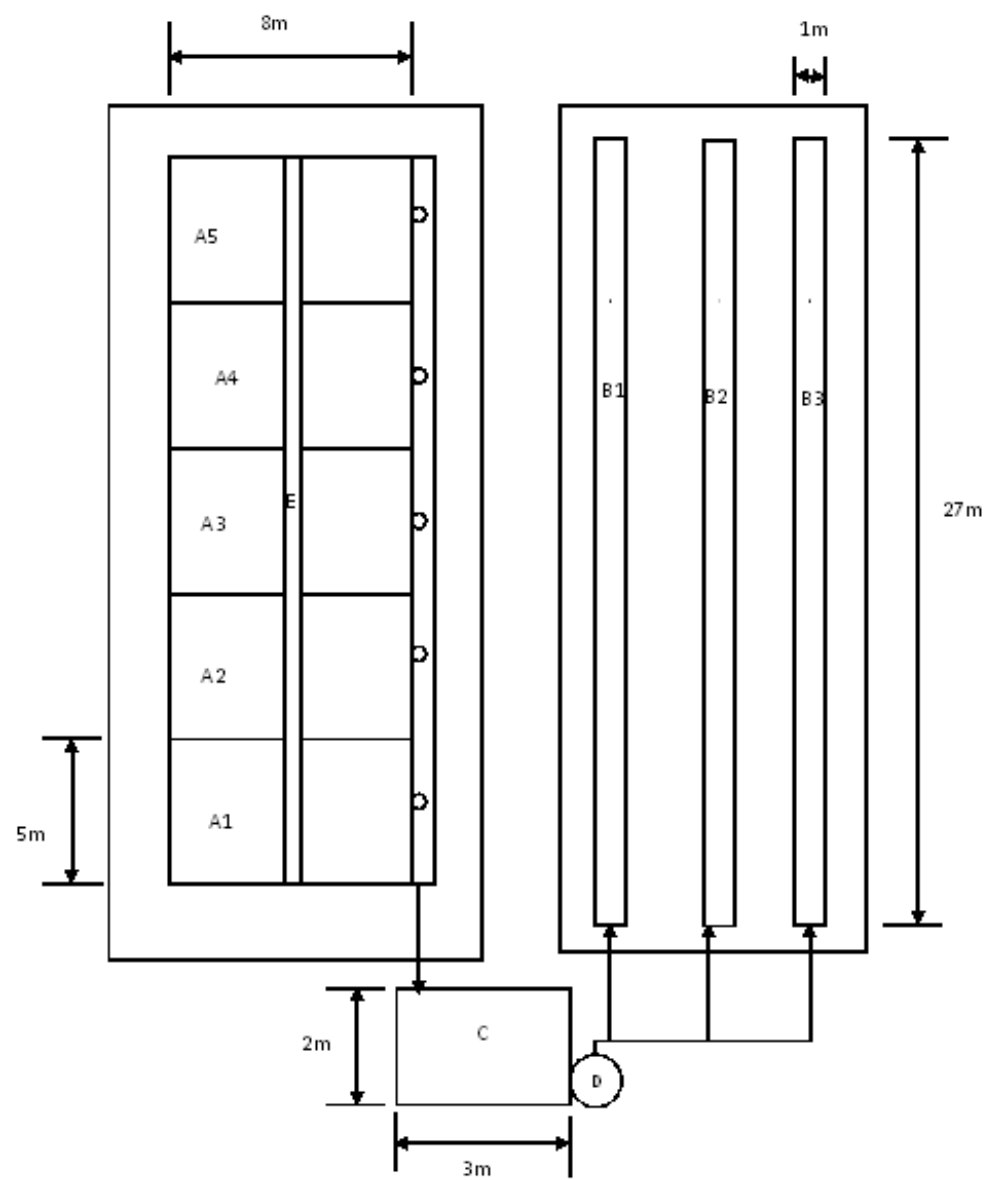

Figure (1): The experimental setup. Fish Tanks, A; Hydroponic Units, B; Bio-sump tank, C; Pump, D; Path way, E.

The hydroponic units in this study consists of three gullies which made from concrete, lined by plastic sheet and covered with foam boards to support the plants. Dimensions of this tank are $27 \mathrm{~m}$ long, $1.0 \mathrm{~m}$ wide and $0.5 \mathrm{~m}$ high with row spacing of $50 \mathrm{~cm}$. Irrigation requirements were determined to 4, 5 and $6 \mathrm{~L} / \mathrm{h} /$ plant according to Ashry (1994).

The solution was pumped from the tank to the upper ends of the gullies. Small tubes were used to supply each gully with water discharged of the fish farm in a closed system.

\subsection{Tomato Plants:}

Tomato seeds were sown in the plastic cups $(7 \mathrm{~cm}$ diameter and $7 \mathrm{~cm}$ height) filled with peatmoss. The cups were irrigated daily using water 
with nutrient solution was prepared manually dissolving appropriate amounts of $\mathrm{Ca}\left(\mathrm{NO}_{3}\right)_{2}, \mathrm{KNO}_{3}, \mathrm{~K}_{2} \mathrm{SO}_{4}, \mathrm{KH}_{2} \mathrm{PO}_{4}, \mathrm{MgSO}_{4}$ and chelates for trace elements into preacidified groundwater, $\mathrm{pH}$ was adjusted to 6.0-7.0 after salt addition. Two weeks old tomato seedlings were planted in the experimental trays according to Roosta, and Hamidpour (2011).

\subsection{Measurements:}

Water samples were taken, at inlet and outlet of the hydroponic units for measuring Ammonia $\left(\mathrm{NH}_{3}\right)$, Nitrite $\left(\mathrm{NO}_{2}\right)$, Nitrate $\left(\mathrm{NO}_{3}\right)$, Phosphorus $(\mathrm{P})$, Potassium (K), Calcium (Ca) and Magnesium (Mg). Ammonia $\left(\mathrm{NH}_{3}\right)$, Nitrite $\left(\mathrm{NO}_{2}\right)$ and Phosphorus $(\mathrm{P})$ measured by a Spekol 11 (Model SPEKOL 11 - Range $0.1-1000$ concentration $\pm 1 \mathrm{~nm} \lambda$, UK). Potassium (K) measured by flame photometer (Model Jenway PFP7 Range 0.1 - 999.9 ppm \pm 0.2 ppm, USA). Calcium (Ca) and Magnesium $(\mathrm{Mg})$ measured by using disodium versenate method as described by Black (1965). Nitrate $\left(\mathrm{NO}_{3}-\mathrm{N}\right)$ content was measured by using salsalic acid as described by Chapman and Partt (1961).

Three tomato plants representing each replicate every month were taken as recommended by (Resh, 1981). Root length, stem diameter, shoot length, number of leaves, shoot and root dry weight were determined. Fresh shoots and roots of tomato plants were weighed and placed in drying oven with circulating air at $65{ }^{\circ} \mathrm{C}$ for $48 \mathrm{~h}$ until constant weight was reached. Fruit yield, fruit weight and number of fruits per plant were also determined at the end of the experiment.

\subsection{Calculations:}

The nutrient consumption was calculated as the differences between the nutrient at inlet and outlet of hydroponic units by the following formula:

$$
N C=\frac{N C_{\text {in }}-N C_{\text {out }}}{\text { Number of plants }} \times Q \times 360
$$

Where:-

$\mathrm{NC}$ is the nutrient consumption, $\mathrm{mg} \mathrm{h}^{-1}$

$\mathrm{NC}_{\mathrm{in}}$ is the nutrient at inlet of the hydroponic unit, $\mathrm{mg} \mathrm{L}^{-1}$

$\mathrm{NC}_{\text {out }}$ is the nutrient at outlet of the hydroponic unit, $\mathrm{mg} \mathrm{L}^{-1}$

$\mathrm{Q}$ is the discharge, $\mathrm{L} \mathrm{h}^{-1}$ 
Water use efficiency (WUS) was determined by the following formula:

$$
W U E=\frac{F \text { ruit Yield }}{\text { Crop Water Uptake }}
$$

Crop water uptake was modelled as a function of leaf area index (LAI) and daily radiation (DR) intercepted by the crop canopy:

$$
C W U=b_{1} \cdot\left(1-e^{-k \cdot L A I}\right) \cdot \frac{D R}{\lambda}+\mathrm{b}_{2}
$$

Where:-

CWU is the crop water uptake

$b_{1}$ and $b_{2}$ are the empirical constants

$\mathrm{k}$ is the canopy light extinction coefficient

$\lambda$ is the latent heat of water vaporization.

Leaf area index was assumed to obey a sigmoid function of accumulated thermal time (expressed as growing degree days, GDD):

$$
L A I=a_{1}+\frac{\left(a_{2}-a_{1}\right)}{1+e^{\left(\frac{a-G D D}{a_{4}}\right)}}
$$

Where:-

$\mathrm{a}_{1}, \mathrm{a}_{2}, \mathrm{a}_{3}$ and $\mathrm{a}_{4}$ are the regression coefficients.

The parameters used in the equations that were obtained from the literature are listed in table (1).

Table (1): The parameters used in the equations.

\begin{tabular}{|l|c|c|}
\hline Parameter & Units & Value \\
\hline $\mathrm{a}_{1}$ & - & -0.335 \\
\hline $\mathrm{a}_{2}$ & - & 4.803 \\
\hline $\mathrm{a}_{3}$ & - & 755.3 \\
\hline $\mathrm{a}_{4}$ & - & 134.7 \\
\hline $\mathrm{b}_{1}$ & - & 0.946 \\
\hline $\mathrm{b}_{2}$ & $\mathrm{~L} \mathrm{~m}^{-2}$ & 0.188 \\
\hline $\mathrm{k}$ & - & 0.69 \\
\hline$\Lambda$ & $\mathrm{Mj} \mathrm{kg}^{-1}$ & 2.45 \\
\hline GDD & - & 1600 \\
\hline
\end{tabular}

\subsection{Statistical analysis:}

The statistical analysis for the data obtained was done according to Snedecor and Cochran (1980) and the treatments were compared using Least Significant Differences (LSD) test at 99\% confidence level (Gomez, 1984). 


\section{RESULTS AND DISCUSSION}

\subsection{Nutrients consumption:}

Any removal of nutrients from the solution can be equated with uptake by plants, provided that the system is free from leaks, algae and regardless of precipitation. Figures ( $2 \mathrm{a}, \mathrm{b}, \mathrm{c}, \mathrm{d}$ and e) show N, P, K, Ca and $\mathrm{Mg}$ consumption by tomato plants at the end of the growing period.

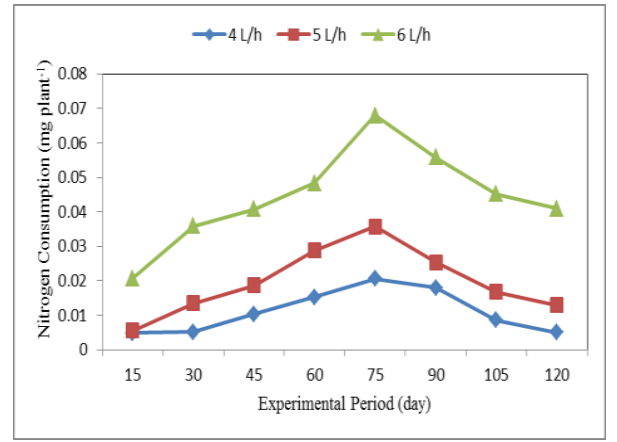

a: Nitrogen consumption

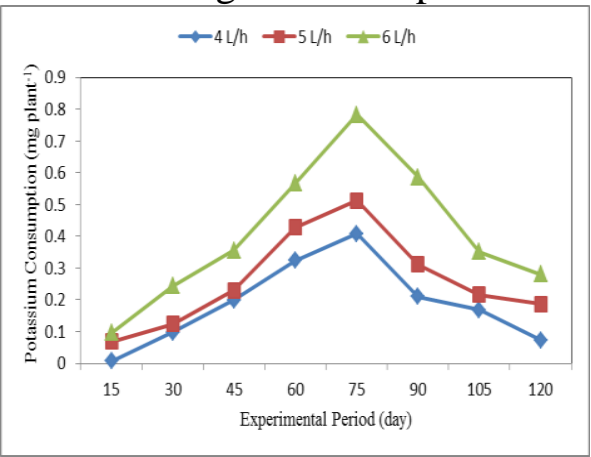

c: Potassium consumption

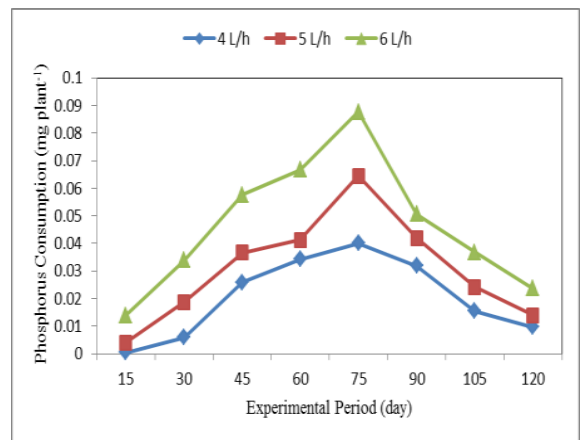

b: Phosphorus consumption

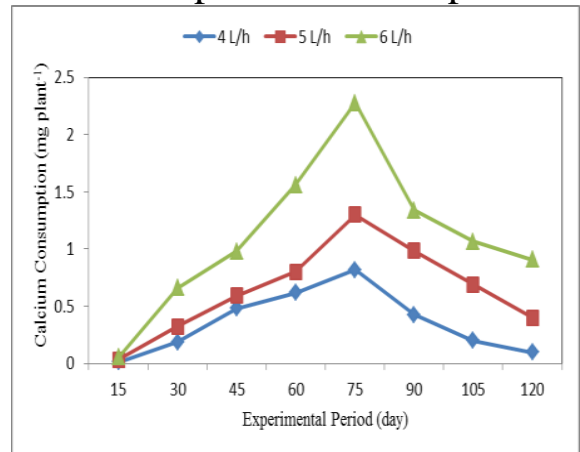

d: Calcium consumption

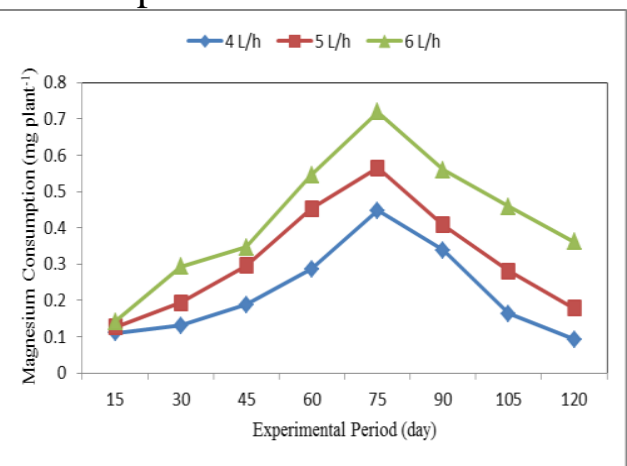

e: Magnesium consumption

Fig (3): a: $\mathrm{N}$ consumption, b: $\mathrm{P}$ consumption, $\mathrm{c}$ : $\mathrm{K}$ consumption, $\mathrm{d}$ : Ca consumption, e: Mg consumption 
The nutrients consumption increase with increasing the flow rate. It indicate that when the flow rate increased from 4.0 to $6.0 \mathrm{~L} \mathrm{~h}^{-1}$, the $\mathrm{N}, \mathrm{P}$, $\mathrm{K}, \mathrm{Ca}$ and $\mathrm{Mg}$ consumption significantly increased from 0.005 to 0.041 (87.80\%), 0.010 to 0.024 (58.33\%), 0.073 to 0.280 (73.93\%), 0.099 to $0.907(89.08 \%)$ and 0.093 to $0.362(74.31 \%) \mathrm{mg} \mathrm{plant}^{-1}$, respectively, at the end of the growing period.

The results also indicate that the nutrients consumption increased gradually until it reached the peak after 75 day and then decreased. These results agreed with those obtained by Cooper (1979).

Multiple regression analysis was carried out to get a relationship between the nutrient consumption ( $\mathrm{NC}, \mathrm{mg}$ plant $\left.^{-1}\right)$, plant age (T, 1-120 day) and flow rate $\left(\mathrm{Q}, 4-6 \mathrm{~L} \mathrm{~h}^{-1}\right)$. The best form was as follows:

$$
\mathrm{NC}=\mathrm{a}+\mathrm{bT}+c \mathrm{Q}
$$

Where:

$\mathrm{a}, \mathrm{b}$ and $\mathrm{c}$ are the constants

The constants of these equations and coefficient of determination are listed in Table 2.

Table (2): The constants a, b, c and coefficient of determination for nutrients consumption at the different times and the different flow rates.

\begin{tabular}{|c|c|c|c|c|}
\hline Items & $\mathrm{a}$ & $\mathrm{b}$ & $\mathrm{c}$ & $\mathrm{R}^{2}$ \\
\hline $\mathrm{N}$ & -0.0657 & 0.0001 & 0.0168 & 0.943 \\
\hline $\mathrm{P}$ & -0.0375 & 0.0008 & 0.0129 & 0.796 \\
\hline $\mathrm{K}$ & -1.475 & 0.0044 & 0.3756 & 0.846 \\
\hline $\mathrm{Ca}$ & -0.3647 & 0.0014 & 0.1108 & 0.838 \\
\hline $\mathrm{Mg}$ & -0.2918 & 0.0013 & 0.1043 & 0.871 \\
\hline
\end{tabular}

\subsection{Plant Growth}

\subsubsection{Root length:}

Figure (3) shows the effect of effluent flow rates on the root length for tomato plants. It indicates that the root length increases with increasing flow rate and plant age. It could be seen that when the flow rate increased from 4.0 to $6.0 \mathrm{~L} \mathrm{~h}^{-1}$, the length of root significantly increased from 19.35 to $28.77 \mathrm{~cm}(32.74 \%)$ and 50.33 to $55.33 \mathrm{~cm}(9.04 \%)$ after 30 and 120 days, respectively, from transplanting. It also indicate that when the time after transplanting increased from 30 to 120 days, the length of root 
significantly increase from 19.35 to 50.33 and 28.77 to $55.33 \mathrm{~cm}$ at 4 and 6 lit $\mathrm{h}^{-1}$ flow rate, respectively.

The highest value of root length was $55.33 \mathrm{~cm}$ was obtained at a flow rate of $6.0 \mathrm{~L} \mathrm{~h}^{-1}$, while, the lowest value of root length was $50.33 \mathrm{~cm}$ was obtained at a flow rate of $4.0 \mathrm{~L} \mathrm{~h}^{-1}$. These results agreed with those obtained by Van Os (1983), Benoit (1987) and Fahim (1989).

Multiple regression analysis was carried out to get a relationship between the root length $(\mathrm{RL}, \mathrm{cm})$, plant age (T, 1-120 day) and flow rate (Q, 4-6 L $\left.\mathrm{h}^{-1}\right)$. The best form was as follows:

$$
\mathrm{RL}=4.3938+0.3006 \mathrm{~T}+3.2613 \mathrm{Q} \quad \mathrm{R}^{2}=0.944
$$

Where:

$\mathrm{RL}$ is the root length, $\mathrm{cm}$

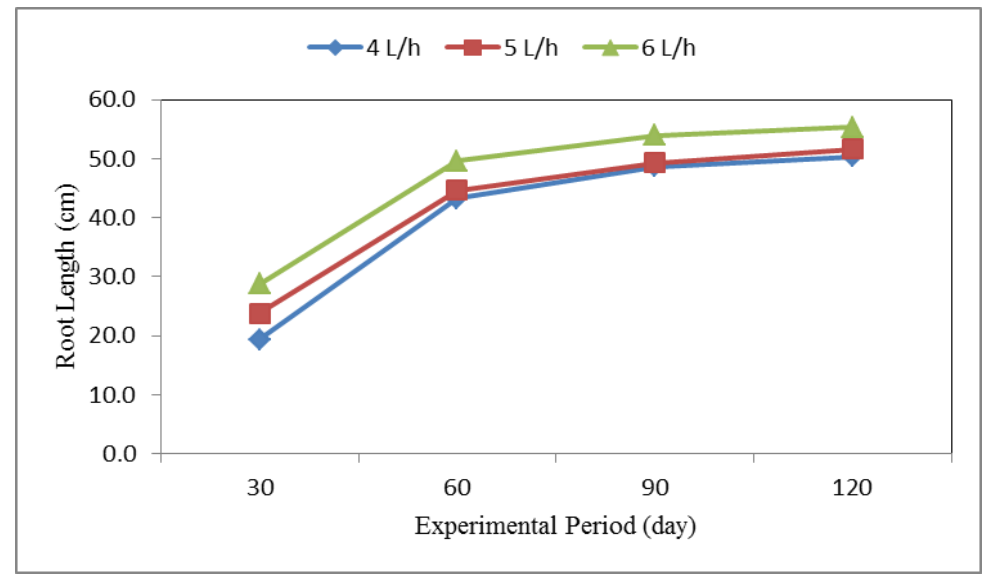

Figure (3): The root length for tomato plants

\subsubsection{Shoot length:}

Figure (4) shows the effect of effluent flow rates on the shoot length for tomato plants. It indicates that the shoot length increases with increasing flow rate and plant age. It could be seen that when the flow rate increased from 4.0 to $6.0 \mathrm{~L} \mathrm{~h}^{-1}$, the length of shoot significantly increased from 33.00 to 53.67 and 149.33 to $191.33 \mathrm{~cm}$ after 30 and 120 days, respectively, from transplanting. It also indicate that when the time after transplanting increased from 30 to 120 days, the length of shoot significantly increase from 33.00 to 149.33 and 53.67 to $191.33 \mathrm{~cm}$ at 4 and $6 \mathrm{~L} \mathrm{~h}^{-1}$ flow rate, respectively. 
Multiple regression analysis was carried out to get a relationship between the shoot length (SL, cm), plant age (T, 1-120 day) and flow rate (Q, 4-6 $\mathrm{L} \mathrm{h}^{-1}$ ). The best form was as follows:

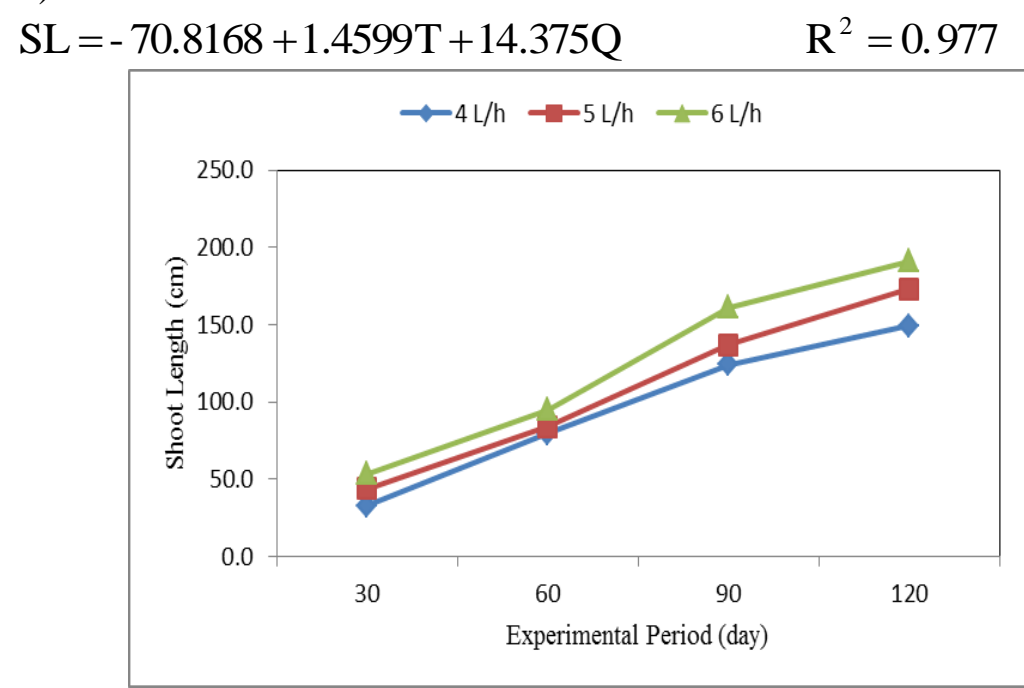

Figure (4): The shoot length for tomato plants

\subsubsection{Number of leaves:}

Figure (5) shows the effect of effluent flow rates on the number of leaves for tomato plants. It indicates that the number of leaves increases with increasing effluent flow rate and plant age. It could be seen that when the flow rate increased from 4.0 to $6.0 \mathrm{~L} \mathrm{~h}^{-1}$, the number of leaves significantly increased from 20.00 to 21.00 and 44.33 to 114.00 after 30 and 120 days, respectively, from transplanting. It also indicate that when the time after transplanting increased from 30 to 120 days, the number of leaves significantly increase from 20.00 to 44.33 and 21.00 to 114.00 at 4 and $6 \mathrm{~L} \mathrm{~h}^{-1}$ flow rate, respectively.

The results indicate that the number of leaves increased gradually until it reached the peak after 90 day and then decreased. The highest value of number of leaves was obtained after about 90 days from transplanting.

Multiple regression analysis was carried out to get a relationship between the number of leaves (NL), plant age (T, 1-120 day) and flow rate (Q, 4-6 $\left.\mathrm{L} \mathrm{h}^{-1}\right)$. The best form was as follows:

$$
\mathrm{NL}=-91.425+0.5802 \mathrm{~T}+23.455 \mathrm{Q} \quad \mathrm{R}^{2}=0.832
$$




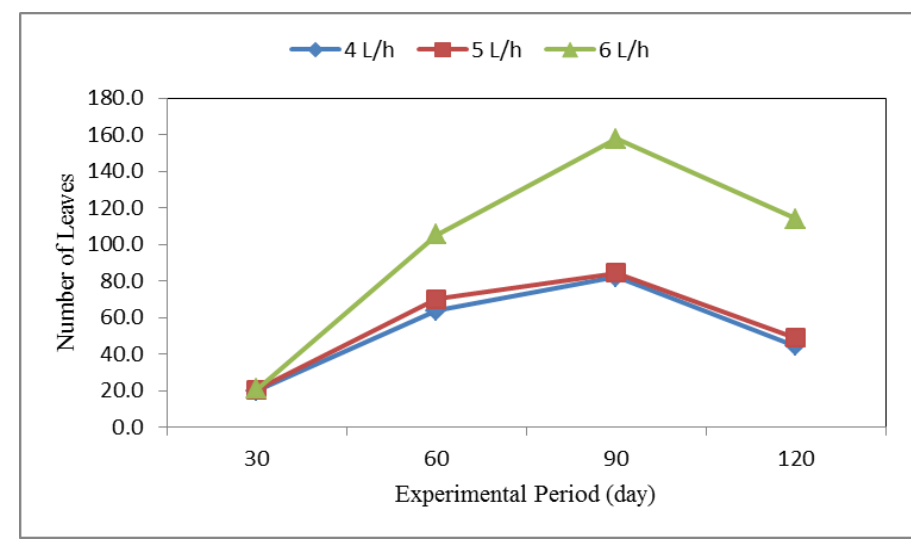

Figure (5): The number of leaves for tomato plants.

\subsubsection{Fresh and dry mass of shoot:}

Figures ( $6 a$ and $b$ ) show the effect of effluent flow rates on the fresh and dry mass of shoot production of tomato plants at the end of growing period. It indicate that when the flow rate increased from 4.0 to $6.0 \mathrm{~L} \mathrm{~h}^{-1}$, the fresh and dry mass of shoot significantly increased from 998.01 to 1372.10 and 83.71 to 275.09 g plant $^{-1}$, respectively.

The highest value of fresh and dry mass of shoot were 1372.10 and $275.09 \mathrm{~g} \mathrm{plant}^{-1}$ was obtained at a flow rate of $6.0 \mathrm{~L} \mathrm{~h}^{-1}$, while, the lowest value of fresh and dry mass of shoot were 998.01 and $83.71 \mathrm{~g} \mathrm{plant}^{-1}$ was obtained at a flow rate of $4.0 \mathrm{~L} \mathrm{~h}^{-1}$.

Increasing fresh and dry weight of shoots was is a results of increasing the length of shoot at 4.0 and $6.0 \mathrm{lit} \mathrm{h}^{-1}$ flow rates may be due to increasing in nutrient consumption rate, as indicated from the data of nutrient consumption.

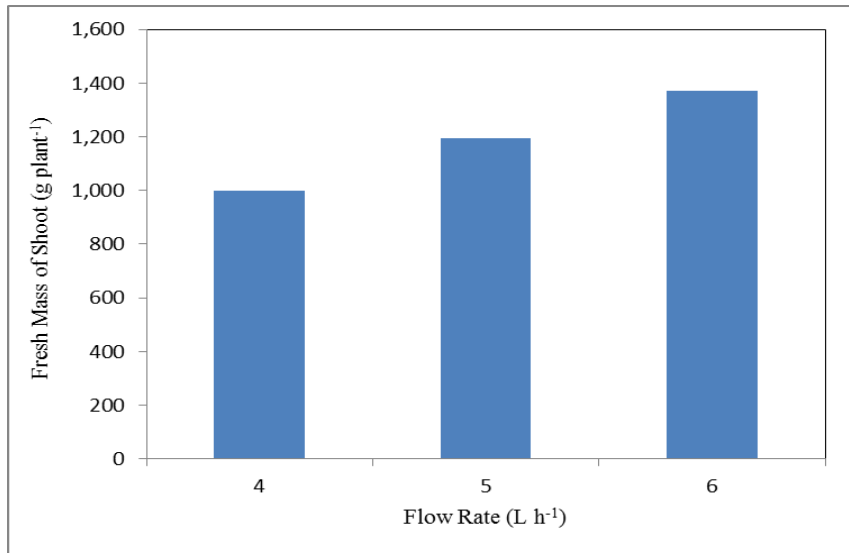

Figure (6a): The effect of effluent flow rates on the fresh mass of shoot production of tomato plants at the end of growing period. 


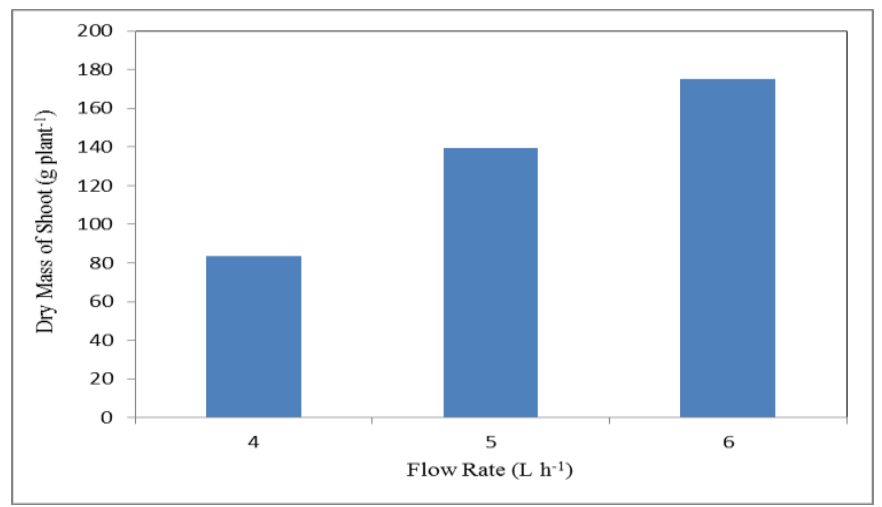

Figure (6b): The effect of effluent flow rates on the dry mass of shoot production of tomato plants at the end of growing period.

\subsubsection{Fresh and dry mass of root:}

Figures ( $7 a$ and $b$ ) show the effect of effluent flow rates on the fresh and dry mass of root production of tomato plants at the end of growing period. It indicate that when the flow rate increased from 4.0 to $6.0 \mathrm{lit}^{-1}$, the fresh and dry mass of root significantly increased from 388.07 to 423.91 and 30.37 to $38.98 \mathrm{~g} \mathrm{plant}^{-1}$, respectively.

The highest value of fresh and dry mass of root were 423.91 and $38.98 \mathrm{~g}$ plant $^{-1}$ was obtained at a flow rate of $6.0 \mathrm{~L} \mathrm{~h}^{-1}$, while, the lowest value of fresh and dry mass of root were 388.07 and $30.37 \mathrm{~g}$ plant $^{-1}$ was obtained at a flow rate of $4.0 \mathrm{~L} \mathrm{~h}^{-1}$.

Increasing fresh and dry weight of roots was concomitant with increasing the length of root at 4.0 and $6.0 \mathrm{~L} \mathrm{~h}^{-1}$ flow rates may be due to increasing in nutrient consumption rate, as indicated from the data of nutrient consumption.

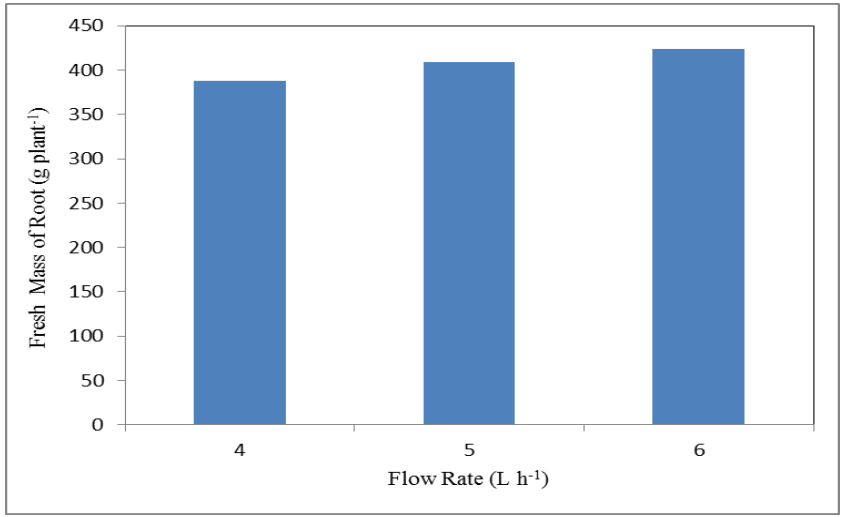

Figure (7a): The effect of effluent flow rates on the fresh mass of root production of tomato plants at the end of growing period. 


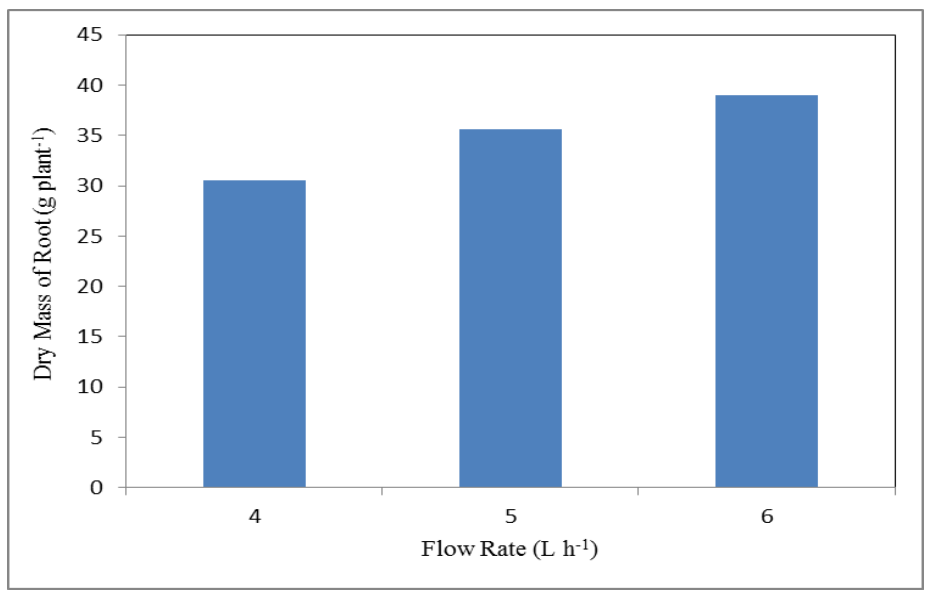

Figure (7b): The effect of effluent flow rates on the dry mass of root production of tomato plants at the end of growing period.

\subsection{Tomato Yield:}

\subsubsection{Fruit yield:}

Figure (8) shows the effect of effluent flow rates on the fruit yield of tomato plants at the end of growing period. The results indicate that the fruit yield increases with increasing effluent flow rate. It indicates that when the flow rate increased from 4.0 to $6.0 \mathrm{~L} \mathrm{~h}^{-1}$, the fruit yield significantly increased from 1.06 to $1.37 \mathrm{~kg} \mathrm{plant}^{-1}$ (22.63\%).

The highest value of fruit yield was $1.37 \mathrm{~kg} \mathrm{plant}^{-1}$ was obtained at a flow rate of $6.0 \mathrm{~L} \mathrm{~h}^{-1}$, while, the lowest value of fruit yield was $1.06 \mathrm{~kg} \mathrm{plant}^{-1}$ was obtained at a flow rate of $4.0 \mathrm{~L} \mathrm{~h}^{-1}$.

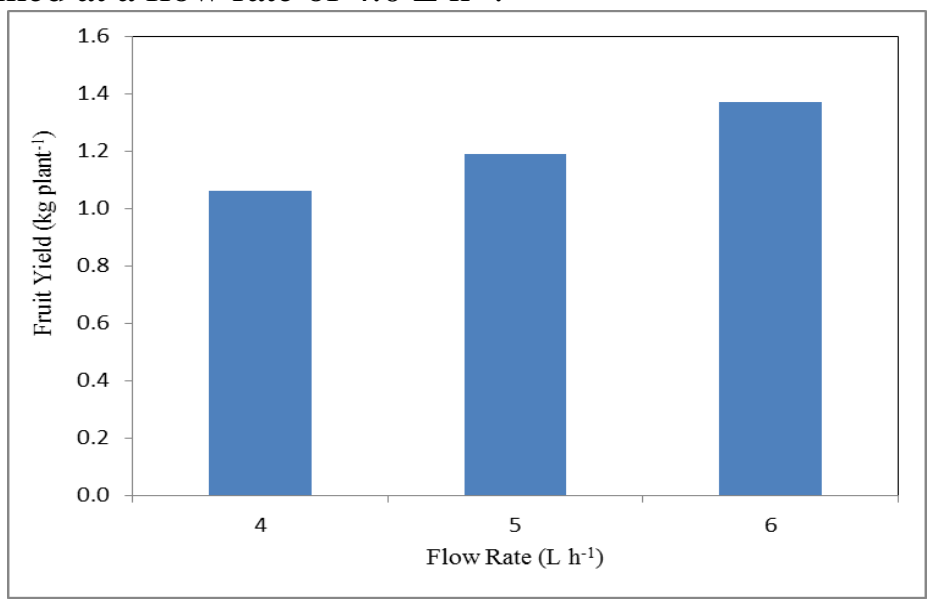

Figure (8): The effect of effluent flow rates on the fruit yield of tomato plants at the end of growing period. 


\subsubsection{Fruit mass:}

Figure (9) shows the effect of effluent flow rates on the fruit mass of tomato plants at the end of growing period. The results indicate that the fruit mass increases with increasing effluent flow rate. It indicates that when the flow rate increased from 4.0 to $6.0 \mathrm{~L} \mathrm{~h}^{-1}$, the fruit mass increased from 75.07 to $81.32 \mathrm{~g}(7.69 \%)$.

The highest value of fruit mass was $81.32 \mathrm{~g}$ was obtained at a flow rate of $6.0 \mathrm{~L} \mathrm{~h}^{-1}$, while, the lowest value of fruit mass was $75.07 \mathrm{~g}$ was obtained at a flow rate of $4.0 \mathrm{~L} \mathrm{~h}^{-1}$.

Increasing fruit mass was concomitant with increasing flow rates may be due to increasing in nutrient consumption rate, as indicated from the data of nutrient consumption.

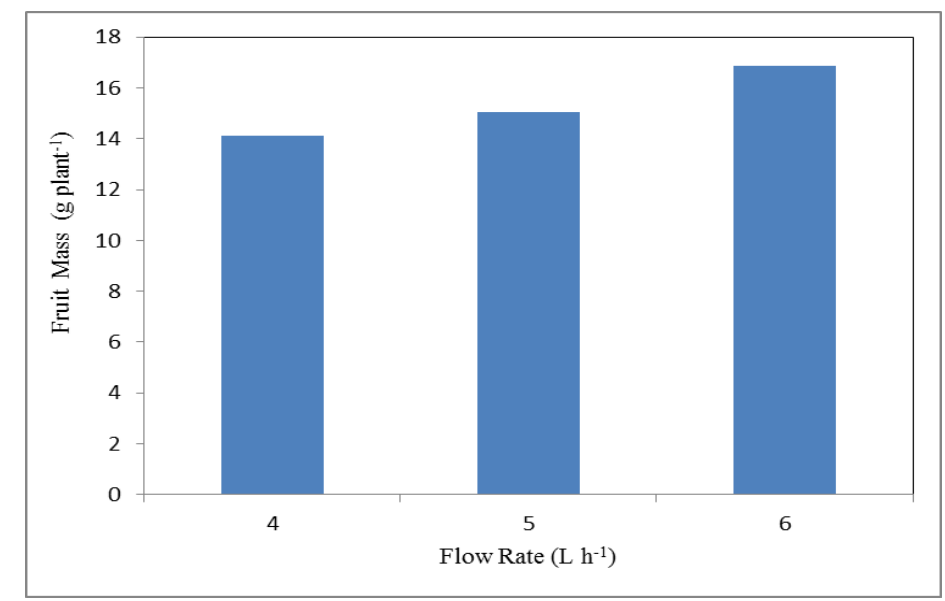

Figure (9): The effect of effluent flow rates on the fruit mass of tomato plants at the end of growing period.

\subsubsection{Number of fruits per plant:}

Figure (10) shows the effect of effluent flow rates on the number of fruits per plant of tomato plants at the end of growing period. The highest value of number of fruits was 16.85 was obtained at a flow rate of $6.0 \mathrm{~L} \mathrm{~h}^{-1}$, while, the lowest value of number of fruits was 14.12 was obtained at a flow rate of $4.0 \mathrm{~L} \mathrm{~h}^{-1}$.

Increasing number of fruits was concomitant with increasing the length of shoot at 4.0 and $6.0 \mathrm{~L} \mathrm{~h}^{-1}$ flow rates may be due to increasing in numbers of node. 


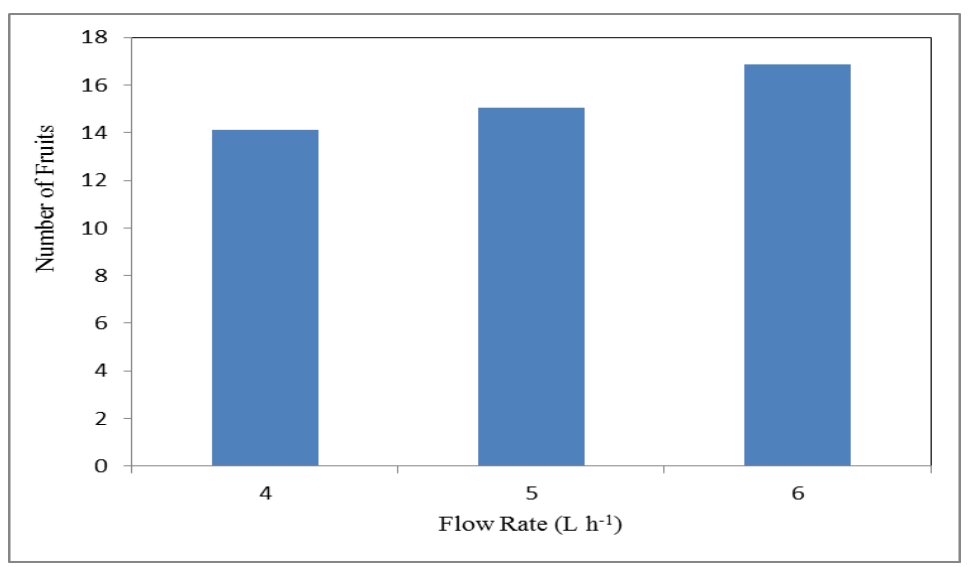

Figure (9): The effect of effluent flow rates on the number of fruits per plant of tomato plants at the end of growing period.

\subsection{Water use efficiency:}

Figure (10) shows the effect of effluent flow rates on the water use efficiency at the end of growing period of tomato plants. The results indicate that the water use efficiency increases with increasing effluent flow rate. It indicates that when the effluent flow rate increased from 4.0 to $6.0 \mathrm{~L} \mathrm{~h}^{-1}$, the water use efficiency increased from 5.54 to $7.16 \mathrm{~kg} \mathrm{~m}^{-3}$ $(22.63 \%)$.

The highest value of water use efficiency was $7.16 \mathrm{~kg} \mathrm{~m}^{-3}$ was obtained at a flow rate of $6.0 \mathrm{~L} \mathrm{~h}^{-1}$, while, the lowest value of water use efficiency was $5.54 \mathrm{~kg} \mathrm{~m}^{-3}$ was obtained at a flow rate of $4.0 \mathrm{~L} \mathrm{~h}^{-1}$.

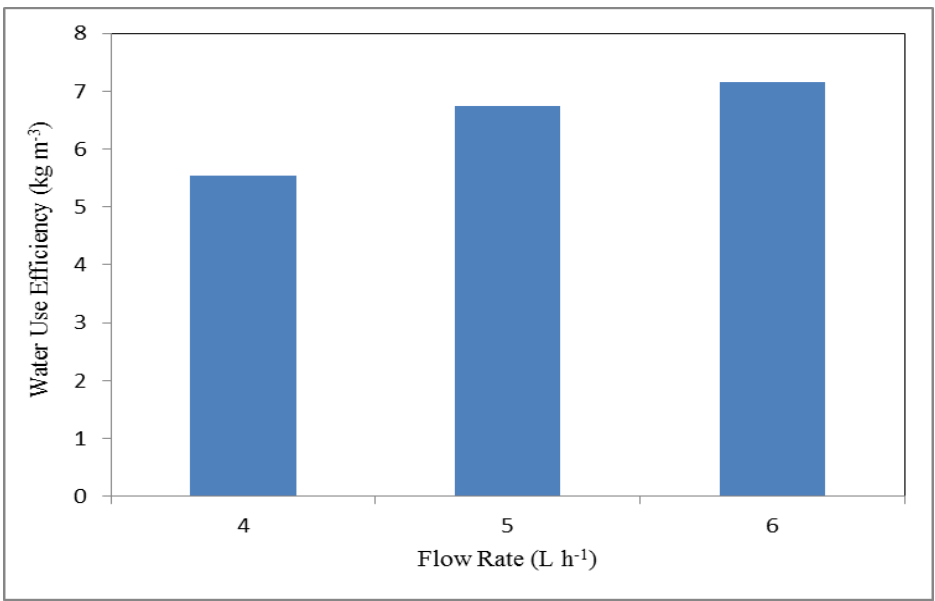

Figure (10): The effect of effluent flow rates on the water use efficiency of tomato plants at the end of growing period. 


\subsection{Feasibility of utilizing the effluent fish farm in tomato cultivation:}

Using the effluent fish farm could save fertilizers which equivalents 0.13 $\mathrm{LE} / \mathrm{kg}$ fruits (130 LE/ton fruits). Besides it is considered as an organic product which is safe for the human health.

\section{CONCLUSIONS}

The experiment was carried out to study to which extent the content of nutrients in water farming is sufficient for growing tomato plants, in order to increase the yield and reduce the production costs. The obtained results can be summarized as follows:

- The nutrients consumption were increased with increasing the flow rate. The $\mathrm{N}, \mathrm{P}, \mathrm{K}, \mathrm{Ca}$ and $\mathrm{Mg}$ consumption significantly increased from 0.005 to 0.041 (87.80\%), 0.010 to 0.024 (58.33\%), 0.073 to 0.280 (73.93\%), 0.099 to $0.907(89.08 \%)$ and 0.093 to $0.362(74.31 \%) \mathrm{mg}$ plant $^{-1}$, respectively, with increasing flow rate from 4.0 to $6.0 \mathrm{~L} \mathrm{~h}^{-1}$.

- The root length increases with increasing flow rate, when the flow rate increased from 4.0 to $6.0 \mathrm{~L} \mathrm{~h}^{-1}$, the length of root significantly increased from 50.33 to $55.33 \mathrm{~cm}(9.04 \%)$ at the end of growing period.

- The shoot length increases with increasing flow rate and time, when the flow rate increased from 4.0 to $6.0 \mathrm{~L} \mathrm{~h}^{-1}$, the length of shoot significantly increased from 149.33 to $191.33 \mathrm{~cm}$ at the end of growing period.

- The fresh and dry mass of shoot significantly increased from 998.01 to 1372.10 and 83.71 to 275.09 g plant $^{-1}$, respectively, with increasing flow rate from 4.0 to $6.0 \mathrm{~L} \mathrm{~h}^{-1}$. The fresh and dry mass of root significantly increased from 388.07 to 423.91 and 30.37 to $38.98 \mathrm{~g} \mathrm{plant}^{-1}$, respectively, with increasing flow rate from 4.0 to $6.0 \mathrm{~L} \mathrm{~h}^{-1}$.

- The fruit yield significantly increased from 1.06 to $1.37 \mathrm{~kg} \mathrm{plant}^{-1}$ with increasing flow rate from 4.0 to $6.0 \mathrm{~L} \mathrm{~h}^{-1}$. The fruit mass and number of fruits increased from 75.07 to $81.32 \mathrm{~g}$ and 14.12 to 16.85 with increasing flow rate from 4.0 to $6.0 \mathrm{~L} \mathrm{~h}^{-1}$, respectively. 
- The water use efficiency increased from 5.54 to $7.16 \mathrm{~kg} \mathrm{~m}^{-3}$ with increasing flow rate from 4.0 to $6.0 \mathrm{~L} \mathrm{~h}^{-1}$. Using the effluent fish farm could save fertilizers which equivalents $0.13 \mathrm{LE} / \mathrm{kg}$ fruits (130 LE/ton fruits). Besides it is considered as an organic product which is safe for the human health.

\section{REFERENCES}

Ashry, M. A. (1994). Environmental control in hydroponic culture. Ph.

D. Thesis, in Agric. Eng., Fac. Agric., Ain-Shams Univ., Egypt.

Benoit, F. (1987). High - technology glasshouse vegetable growing in Belgium. Soilless culture, 3(1): 21-29.

Benoit, F. and N. Ceustermans (1989). Recommendations for the commercial production of Butterhead lettuce in NFT. Soilless Culture, 5(1): 1-12.

Black, C. A. (1965). Methods of soil analysis. Part 2, chemical and microbiological properties. Am. Soc. Of Agron., Pub., Madison, Wisc., USA: 999-1010.

Bromes, B. (2002). Aquaponics. Email: bromes @ bromes. Com

Chapman, H. D. and F. P. Partt (1961). Methods of analysis of soils, plant and water. Cal. Univ., 150-200.

Cooper, A. J. (1979). "The ABC of NFT", $2^{\text {nd }}$. Ed. Grower Books. England.

Diver, S. (2000). Aquaponics - integration of hydroponics with aquaculture. www. Attar. Ncat. Org.

Fahim, M. M. (1989). Design of nutrient film system for agriculture under green-house, M. SC. Thesis, in Agric., Mech., Col. Agric., Ain-shams Univ., 150 pp. (Arabic, Engl. Summary).

FAO (2012). Production crops. Fifteen edition. Roma, Italy

Gomez, K. A. (1984). Statistical procedures for agricultural research. $2^{\text {nd }}$ ed. John Wiely \& sons, New York, USA, 680 pp.

Graber, A. and R. Junge (2009). Aquaponic systems: nutrient recycling from fish wastewater by vegetable production. Desalination 246, 147-156. 
Graves, C. J. and R. G. Hurd (1983). Intermittent solution circulation in the nutrient film technique. Acta Hort., 133: 47-52.

Johnson, D. M. And G. W. Wardlow (1997). A prototype recirculating aquaculture - hydroponic system. J. of Agricultural Mechanization.

Karen, I. (2005). Aquaponics from global aquatics turning waste into profits. www. aquaranch. Com.

Khater, E. G. (2006). Aquaponics: the integration of fish and vegetable culture in recirculating systems. M. Sc. Thesis, in Agric. Eng., Fac. Agric., Moshtohor, Benha Univ., Egypt.

Khater, E. S. and S. A. Ali (2105). Effect of flow rate and length of gully on lettuce plants in aquaponic and hydroponic systems. J. of Aquac. Res. and Devel., 6: 3. http://dx.doi.org/10.4172/21559546.1000318

Lee, C. S. (2004). Aquaponics, An integrated fish culture and vegetable hydroponics production system. www. growingedge. Com.

Nelson, R. L. (2006a). Aquaponics -Hydroponics- Aquaculture. Aquaponics journal, Article Reprints, contact at Aquaponics journal, maitto: inf @ aquaponics. Com.

Nelson, R. L. (2006b). Information on aquaponics and aquaculture. Aquaponics journal, Article Reprints, contact at Aquaponics journal, maitto: inf @ aquaponics. Com.

Nelson, R. L. (2006c). The source for information on aquaponics and aquaculture. Aquaponics journal, Article Reprints, contact at Aquaponics journal, maitto:

Nelson, R. L. (2008). Aquaponic Food Production. Nelson and Pade Inc. Press, Montello, WI, USA, 218 pp.

Okimoto, D. K. (2004). Aquaponics export conducts workshops in American Samoa. www. aginclassroom. Org .

Rackocy, J. E., D. S. Bailey, K. A. Shultz and W. M. Cole (1997). Evalution of a commercial-scale aquaponic unit for the production of tilapia and lettuce. In K. Fitzsimmons, Ed. Tilapia Aquaculture: Proceeding of the fourth International Symposium on Tilapia in Aquaculture, Orlando, Florida, pp. 357-372. 
Rackocy, J. E., J. A. Hargreaves (1993). Integration of vegetable hydroponics with fish culture: a review. In: J. K. Wang, Ed. Techniques for Modern Aquaculture. American Society of Agricultural Engineering, St. Joseph, MI, pp. 112-136.

Rackocy, J. E., J. A. Hargreaves and D. S. Bailey (1993). Nutrient accumulation in a recirculating aquaculture system integrated with vegetable hydroponic production. In: J. K. Wang, Ed. Techniques for Modern Aquaculture. American Society of Agricultural Engineering, St. Joseph, MI, pp. 148-158.

Rakocy, J. E. (2002). Aquaponics: vegetable hydroponics in recirculating systems. jrakocy @ uvi. edu.

Resh, H. M. (1981). Hydroponic food production. Woodbridge press Pub. Co.

Roosta, H. R. and M. Hamidpour (2011). Effect of foliar application of some macro- and micro-nutrients on tomato plants in aquaponic and hydroponic systems. Scientia Horticulturae, 129: 392 - 402.

Selock, D. (2003). An introduction to aquaponics: the symbiotic culture of fish and plants. www. Siu. Edu/ readi.

Sikawa, D. C. and A. Yakupitiyage (2010). The hydroponic production of lettuce (Lactuca sativa L) by using hybrid catfish (Clarias macrocephalus $\times$ C. gariepinus) pond water: Potentials and constraints.Agricultural Water Management, 97: 1317 - 1325.

Snedecor, G. W. and W. G. Cochran (1980). Statistical methods, $7^{\text {th }}$ (Ed), Iowa State Univ. Press, Ames, Iowa, USA.

Suits, B. (2010). Access to personal agriculture. The Aquaponics Guidebook, Volume 1, 2nd Edition, pp. 1-12.

Tucker, C. S. and C. E. Boyd (1985). Water quality, channel catfish culture. In: C. S. Tucker (ed). Elsevier Sci. Publ. Co., Amesterdam, The Nether lands.

Van Os, E. A. (1983). Dutch developments in soilless culture. Outlook in Agriculture. 


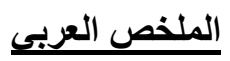

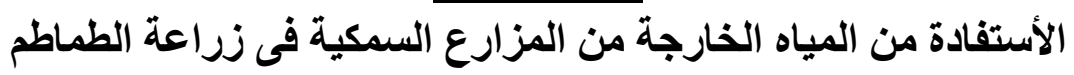

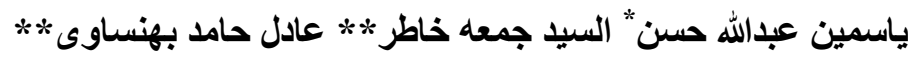

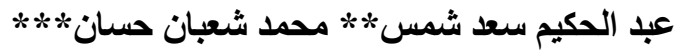

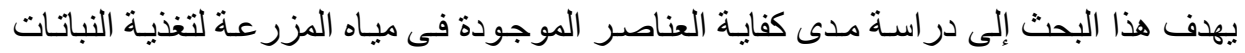

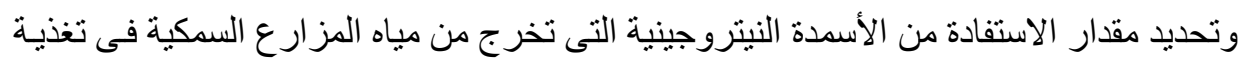

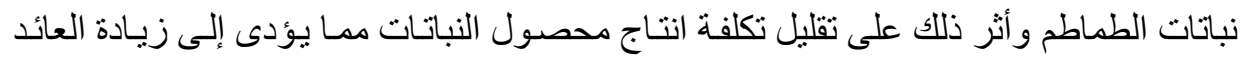

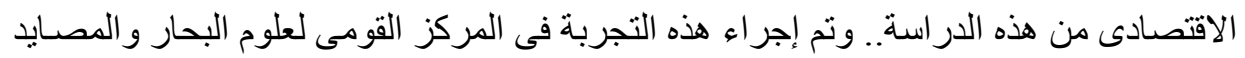

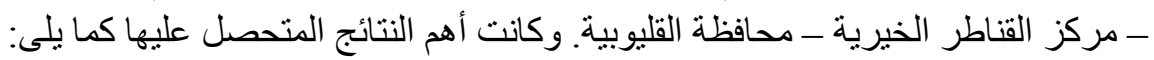

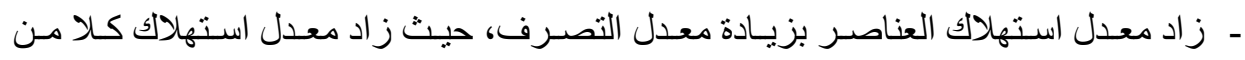

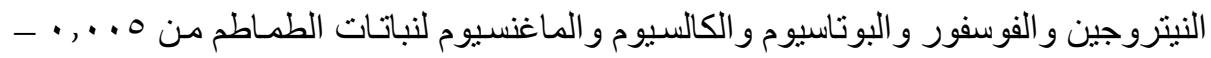

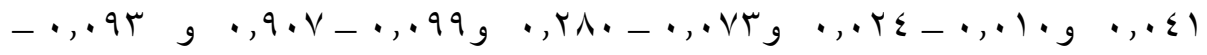

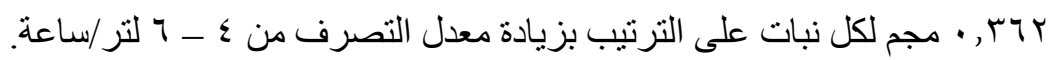

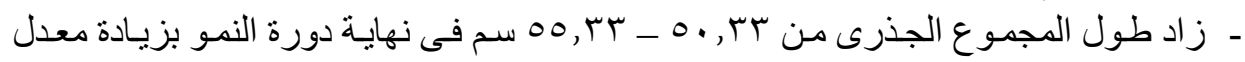

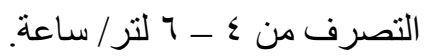

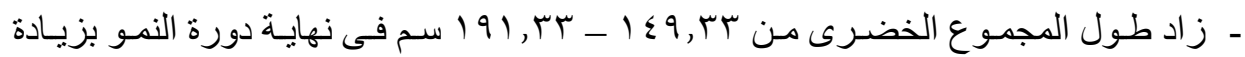

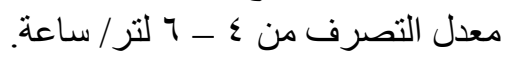

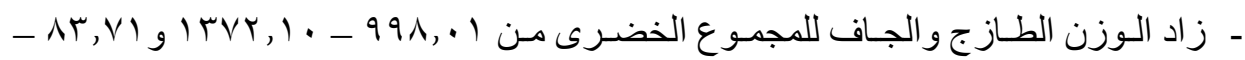

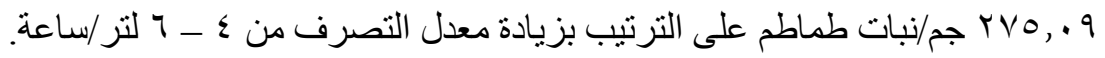

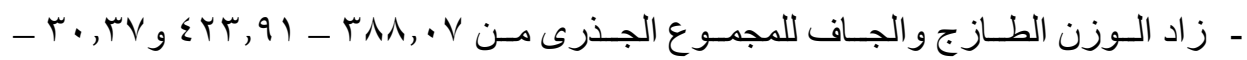

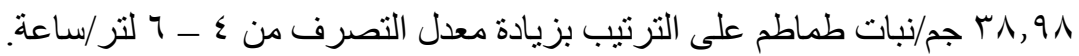

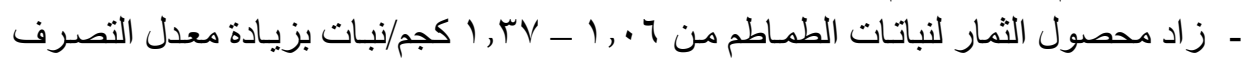

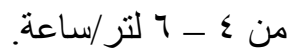

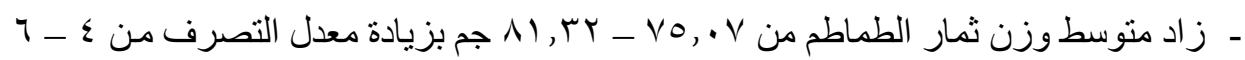
لتر/ساعة.

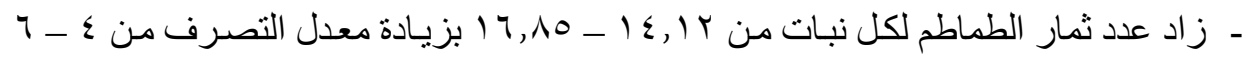

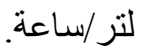

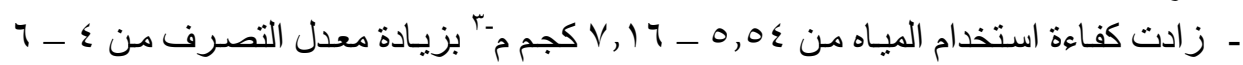
لتر/ساعة.

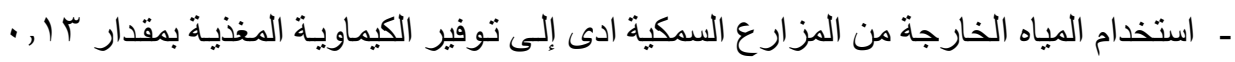

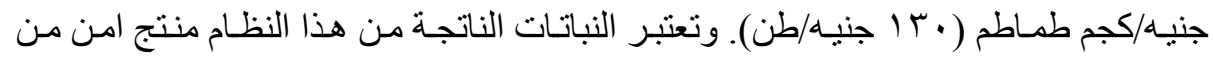
الناحية الصحية على المستهلك.

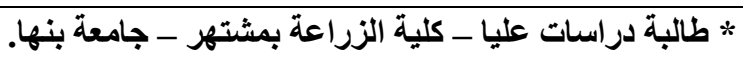

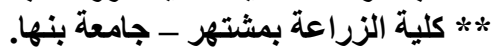
*** المركز القومى لعلوم البحار والمصايـ. 